ks. dr hab. Jan Klimek ${ }^{1}$

ORCID: 0000-0002-6333-8215; jan.klimek@upjp2.edu.pl

Uniwersytet Papieski Jana Pawła II w Krakowie

\title{
Spowiedź osób z zaburzeniem psychicznym
}

\section{Streszczenie}

Obecność dużej liczby osób z zaburzeniami psychicznymi wśród wiernych Kościoła katolickiego wymaga pogłębionej refleksji duszpasterskiej na temat podejścia do nich. Są obdarzeni szczególną wrażliwością i ponadprzeciętnymi potrzebami duchowej opieki. Kościół stara się wspierać takich ludzi, kształtując wrażliwość na ich obecność w różnych środowiskach i wzywając do objęcia takich osób opieką. Artykuł stanowi konceptualizację specyfiki zaburzeń psychicznych w kontekście sakramentu spowiedzi i zaproponowano w nim zestaw zasad działania umożliwiających jej właściwe przeżycie przez te osoby.

Słowa kluczowe: zaburzenie psychiczne, spowiedź, przygotowanie

\section{Abstract}

\section{Confession of People with Mental Disorder}

The presence of a significant number of people with mental disorders among the faithful of the Catholic Church requires in-depth pastoral reflection on how to approach their needs. They form a specific group in society, as they are endowed with special sensitivity and above-average needs of spiritual care. The Church strives to support such people by constantly calling for care and sensitivity to their presence in various environments. This article attempts to conceptualize the specificity of mental disorders in the context of the sacrament of penance and reconciliation. Moreover, a set of operating principles has been suggested that will enable people affected by mentioned above disorders to experience the sacrament properly.

Keywords: mental disorder, confession, preparation

1 Ks. Jan Klimek - adiunkt w Katedrze Teologii i Psychologii Pastoralnej Wydziału Teologicznego UPJPII; od 2008 roku łączy pracę naukową z posługą duszpasterską kapelana w Szpitalu Klinicznym im. dr. Józefa Babińskiego w Krakowie oraz rektora Rektoratu pw. Matki Bożej Częstochowskiej w Krakowie; autor m.in.: Duszpasterstwo w kobierzyńskiej kapelanii na przestrzeni wieku (Kraków 2019), współautor: Odnaleźć wykluczonych (Kraków 2014), Środowisko a zdrowie psychiczne człowieka (Kraków 2015), Wspomóc uzależnionych od alkoholu (Kraków 2017). 
W posłudze duszpasterskiej w każdym środowisku pastoralnym szczególną rolę pełni sakrament pojednania. Dla jego szafarza zawsze wiąże się on z wielką odpowiedzialnością za słowa wypowiadane wobec penitenta.

Trudność szafowania tego sakramentu narasta w sytuacji kontaktu kapłana z wiernym przeżywającym dysfunkcje psychiczne. Choroby psychiczne, zakorzenione w środowisku społecznym chorego i czerpiące z niego elementy wytwórcze (na przykład obrazy psychotycznych wizji), również zakorzeniają się w głębi osobowości człowieka chorego, dotykając, choć nie zawsze całościowo, najgłębszych jego wymiarów i doświadczeń, z doświadczeniem religijnym i etycznym włącznie.

\section{Sumienie i psychika w kontekście duchowo-cielesnej wizji człowieka}

Chrześcijaństwo za całościową koncepcję biblijną postrzega człowieka jako jedność duchowo-cielesną, a więc jako istotę obdarzoną zarówno fizycznym ciałem, jak i rozumną duszą, która jest nieśmiertelna. Żaden z tych dwóch wymiarów członów składających się na całość osoby ludzkiej nie może być uważany za podrzędny względem drugiego². W związku z tym w pracy z osobami z zaburzeniem psychicznym należy uwzględnić pomoc medyczną i duchową, które powinny być prowadzone równolegle z pracą duszpasterską ${ }^{3}$. Bardzo trudnym zadaniem jest odróżnienie źródła treści, jakie pojawiają się w umyśle tych osób. Część z nich może mieć podłoże psychopatyczne i być wynikiem zaburzenia, także na tle religijnym, a część może stanowić przestrzeń do pracy duszpasterskiej, szczególnie w dziedzinie oceny moralnej przeżyć wewnętrznych i czynów zewnętrznych oraz obrazu Boga. Wiele zaburzeń psychicznych powoduje zanik świadomości rozumianej jako prawidłowe postrzeganie rzeczywistości w samym sobie oraz otaczającym świecie. To zjawisko może być jakościowe (tzn. dotyczyć zniekształconego

2 Por. Jan Paweł II, Mężczyzna i niewiasta stworzył ich. Chrystus odwołuje się do zmartwychwstania, Lublin 2006, s. 30. M. Krąpiec, Człowiek i prawo naturalne, Lublin 1993, s. 117.

3 Por. B. de Barbaro, Najlepiej pomoc równoległa, „Więź” 2 (2004) nr 544, s. 21-22. 
postrzegania rzeczywistości) oraz ilościowe - mogące objawiać się brakiem przytomności, skutkującym deficytami poznawczymi wobec niektórych faktów ${ }^{4}$. Takie dolegliwości są charakterystyczne dla wielu zaburzeń psychicznych. Najsilniej występują w przypadkach schizofrenii, zaburzeń pamięci, zespołów majaczeniowych i omamowych, uzależnień od substancji chemicznych ${ }^{5}$.

Ocena moralna popełnionych czynów wiąże się w dużej mierze z ich świadomością ${ }^{6}$, dlatego pierwszym zadaniem w przypadku spowiedzi osób z zaburzeniem psychicznym będzie określenie tego, za co tak naprawdę są odpowiedzialni. Tacy ludzie często są doświadczeni różnorakim złem, które spowodowali wobec otoczenia i samych siebie. Może ono mieć różny charakter: od drobnych niedociągnięć, przez zburzone relacje, aż po bardzo poważne czyny, które w innych okolicznościach podlegają odpowiedzialności prawnej. Najbardziej widocznym symptomem źle działającego sumienia, które może być naznaczone zaburzeniem psychicznym, są silne i nieadekwatne do przeżywanej sytuacji wyrzuty sumienia i związane z nimi emocje. Dotyczy to zwłaszcza osób neurotycznych. Wówczas poczucie winy występuje jako przeceniona idea, a mechanizmem podsycającym je jest superego, mogące przybierać pozory sumienia. Podstawowa różnica między superego a sumieniem może być rozpatrywana w kontekście przymusu. Sumienie jest wyrazem miłości i w związku z tym niczego nie nakazuje, ale bada co jest słuszne, staje się dynamiczne i otwarte na świat zewnętrzny (także wskazania innych osób i możliwość zmiany wartości), uwzględnia kontekst i okoliczności ocenianych doświadczeń, ukierunkowuje się na przyszłość, w której dostrzega szansę na zmianę (uwzględnia miłosierdzie i możliwość poprawy). Superego natomiast zajmuje pozycję autorytarną, w której

4 Por. R. Mazur, M. Klimarczyk, M. Trzcińska, W. Rajczyk, Zaburzenia świadomości-spojrzenie interdyscyplinarne, „Polski Przegląd Neurologiczny” 10 (2014) nr 2, s. 51-58.

5 Por. D. Kurpas, H. Miturska Podstawy psychopatologii i syndromologii ogólnej, w: Podstawy psychiatrii dla studentów pielęgniarstwa, red. D. Kupis, H. Miturska, M. Kaczmarek, Wrocław 2009, s. 33-48.

6 Por. Katechizm Kościoła katolickiego, Poznań 1994, 1854-1861; Kodeks Prawa kanonicznego, Poznań 1984, kan. 1324; Jan Paweł II, Reconcilatio et penitenitia, 17, http://www.vatican. va/content/john-paul-ii/pl/apost_exhortations/documents/hf_jp-ii_exh_02121984_reconciliatio-et-paenitentia.html (20.12.2020). 
dyktuje i nakazuje stałe, utarte schematy postępowania, uwypukla przede wszystkim doświadczenia z przeszłości oraz bardziej akcentuje karę i negatywne konsekwencje niż możliwość moralnego rozwoju ${ }^{7}$. Sumienie w tym przypadku powinno być postrzegane jako akt rozpoznania wartości czynu w konkretnej sytuacji, a nie jako wewnętrzny głos, który może być pomylony z fałszywymi treściami dyktowanymi przez zaburzoną psychikę 8 .

Innym czynnikiem wymagającym intensywnego wsparcia duchowego jest obraz Boga w percepcji osób z zaburzeniem psychicznym. Bardzo często jest on nieadekwatny do wykładni chrześcijańskiej ${ }^{9}$. Osoba z zaburzeniami nerwicowymi i o nasilonych lękach najczęściej rozumie Boga jako srogiego sędziego, który jedynie wymaga oraz egzekwuje kary za popełnione błędy i grzechy. Powstają wówczas dwa rodzaje napięć: (1) pomiędzy zakładanymi ideałami a odległą od nich rzeczywistością oraz (2) między dążeniami o podłożu religijnym (osadzonymi na wysokim poziomie wymagań) a własnymi możliwościami. Niekiedy też (szczególnie w urojeniach wyższościowych) obecne jest silne przeświadczenie o posiadaniu specjalnych mocy nadprzyrodzonych bądź byciu kimś szczególnym np. Mesjaszem lub szatanem. Niewłaściwe wychowanie religijne, przewartościowanie niektórych zasad moralnych, a także przesadna projekcja negatywnych cech ludzkich na obraz Boga mogą powodować, że dana osoba nie jest w stanie przeżywać w zdrowy sposób swojej religijności. Niewłaściwie pojmowane treści religijne często stanowią istotę zaburzeń psychicznych klasyfikowanych jako nerwice eklezjogenne ${ }^{10}$.

7 Por. J. Prusak, Rozróżnianie sumienia od superego u osób religijnych w kontekście pracy z nerwica eklezjogenna, „Psychoterapia” 4 (2016) nr 179, s. 33-44.

8 Por. J.A. Kłoczowski, Sumienie a superego, czyli paradoksalna bliskość Tomasza z Akwinu i Freuda, w: Między konfesjonałem a kozetka, red. K. Jabłońska, C. Gawryś, Warszawa 2010, s. 121-133.

9 M. Walczak, Problem tak zwanego obrazu Boga w świetle tezy Paula Tillicha o objawieniu finalnym, „Teologia w Polsce” 10 (2016) nr 2, s. 197-207.

10 Por. A. Molenda, Wybrane aspekty nerwicy eklezjogennej. Perspektywa psychoterapeuty, w: Religia, religijność, duchowość: w poszukiwaniu nowych perspektyw: księga jubileuszowa dla Pawła M. Sochy od przyjaciół i uczniów, red. H. Grzymała-Moszczyńska, D. Motak, Kraków 2015, s. 189-199. 
Dobrze prowadzona terapia ma za zadanie m.in. ukazanie prawdy o osobie, która ją przechodzi. Dalszą konsekwencją permanentnego leczenia danego zaburzenia powinna być trwała zmiana życiowa. W tym zadaniu pomocna może być dobrze przeżywana spowiedź. Wgląd pacjenta we własną psychikę powinien być spójny z rachunkiem sumienia, jaki przeprowadza on przed przystąpieniem do sakramentu pokuty i pojednania. To wymaganie jest istotne dla obu stron: terapeuty/lekarza podejmującego leczenie, aby uwzględnił potrzeby duchowe pacjenta, oraz duszpasterza, który jest zobowiązany do utrzymania kierunku posługiwania duszpasterskiego niekolidującego $\mathrm{z}$ formą podjętej terapii ${ }^{11}$. Ewentualna niespójność w podejściu tych specjalistów najczęściej nie wynika z konfliktu między nimi, a raczej znierozpoznania podczas sakramentu pokuty i pojednania tego, co jest skutkiem złej woli penitenta, a co efektem dysfunkcji psychologicznych ${ }^{12}$.

\section{Język symboliczny u osób z zaburzeniem psychicznym}

Osoby z zaburzeniem psychicznym, szczególnie w okresie hospitalizacji, przeżywają swoją spowiedź, komunikując stany duchowe często językiem specyficznym, znacznie odbiegającym od typowego wyznania penitenta w konfesjonale. Jest to język zarówno symboliczny, a więc odnoszący się do rzeczywistości uniwersalnych, jak też język oparty na „znakach” skonstruowanych przez penitenta w procesie przeżywania specyficznie swojego doświadczenia psychicznego. Ta symbolizacja jest procesem ułatwiającym pacjentowi-penitentowi zarówno proces komunikacji na zewnątrz (z kapłanem), jak i opisania, a także zrozumienia własnych duchowych przeżyć. Symbolizację należy odróżnić od innych werbalnych zaburzeń myślenia (np.: swobodne skojarzenia, czyli wyrażanie niepowiązanych, ale następujących po sobie myśli, niemających logicznego związku), które dla spowiednika są już znakiem, że penitent na tym etapie terapii nie jest jeszcze dysponowany do sakramentu pojednania. Dla niego spotkanie z szafarzem sakramentu pojednania winno

11 Por. K. Kotowa, Punkty styczne, „Więź” 2 (2004) nr 544, s. 26.

12 Por. L. Niewiadomski, Integralnie, „Więź” 2 (2004) nr 544, s. 30. 
być okazją do rozmowy duszpasterskiej zakończonej błogosławieństwem, ale nie podniesionej do rangi sakramentu. I należy o tym pacjentowi wyraźnie powiedzieć ${ }^{13}$.

W praktyce pastoralnej wobec osób zaburzonych psychicznie, szczególnie w okresie hospitalizacji, zachować należy jednak daleko posuniętą łagodność duszpasterską (benignitas pastoralis) mającą swoje źródło w miłosierdziu Pana, który nie przyszedł przecież do zdrowych, ale do tych, którzy się źle mają (por. Mk 2, 17). Język symboliczny jest trudny do odczytania i może u szafarza rodzić odczucie braku dyspozycyjności u penitenta nie tylko dlatego, że domaga się głębszej znajomości pacjenta i jego wewnętrznych przeżyć (stąd sakrament spowiedzi i pojednania powinien być sprawowany jako kolejny kontakt duszpasterski z pacjentem), ale też dlatego, że często nie wiąże się z właściwą mową ciała (body language ${ }^{14}$. Typowe dla schizofrenii objawy ubytkowe (negatywne) takie, jak zblednięcie emocji, zmniejszenie motywacji do działania, zobojętnienie emocjonalne, lakoniczność wypowiedzi nie świadczą o braku dyspozycji do sakramentu pojednania. Pewien brak spójności i nieadekwatność pomiędzy słowem i jego logiczną strukturą a mową ciała nie musi znamionować braku dyspozycji do przeżywania sakramentu pokuty i pojednania, ale jedynie utrudnienie w jego przeżywaniu $^{15}$.

Trzeba też wziąć pod uwagę proces stratyfikacji doświadczeń psychicznych osób poddawanych hospitalizacji psychiatrycznej. W czasie epizodów psychotycznych bywa tak, że w istotnych obszarach życia pacjent doświadcza utraty poczucia rzeczywistości, ale w obszarze swojej duchowości i religijnego doświadczenia zachowuje jednak właściwy osąd sytuacji. Pacjent zmagający się z urojeniami paranoidalnymi

13 Por. J. M. Dołęga, Analiza pojęcia symbolu, „Studia Philosophiae Christianae” 39 (2003) $\mathrm{nr}$ 2, s. 77-95. J.F. Jacko, Struktura symboli wertykalnych a ich rola w komunikacji międzykulturowej i w zarządzaniu, „Space - Society - Economy” 7 (2005) nr 7, s. 176-183.

14 Por. J. Klimek, Duszpasterstwo w kobierzyńskiej kapelanii na przestrzeni wieku, Kraków 2019, s. 310-312.

15 Por. A. Czernikiewicz, Jak żyć ze schizofrenia - poradnik dla pacjentów i ich rodzin, Lublin 2009, s. 4. N. Andersch, Symbolic Form and Mental Illness: Ernst Cassirer's Contribution to a New Concept of Psychopathology, w: The Philosophy of Ernst Cassirer: A Novel Assessment, ed. S. Luft, J. Tyler Friedman, Berlin 2015. s. 163-198. 
i twierdzący na przykład, że lekarz psychiatra usiłuje podać mu truciznę ma jednocześnie świadomość, że zwyzywał go wulgarnymi słowami i życzył mu źle. Składowe ludzkiej osobowości i świadomości w różnym stopniu podlegają zaburzeniu na skutek procesu chorobowego. Psychoza w różnym stopniu dezorganizuje poziomy świadomości ${ }^{16}$.

Właściwą odpowiedzią na symboliczny język pacjenta, związany z jego doświadczeniem psychotycznym, powinien być ewangeliczny język szafarza sakramentu. Gdy kapłan sprawujący sakrament pojednania odwołuje się częściej do ewangelicznych i biblijnych obrazów, tym samym tworzy archetypiczną i jednocześnie symboliczną przestrzeń dialogu, w której łatwiej zrozumieć symboliczny język pacjentów. Co więcej, symboliczność biblijnych (ewangelicznych) obrazów odnosi uczestników sakramentalnego dialogu do najgłębszych i najstarszych doświadczeń religijnych wspólnoty Kościoła i każdego z jej członków osobiście. Odnoszenie się do doświadczenia w wierze $\mathrm{z}$ przeszłości jest również otwarciem na nową przyszłość. Ten sam fragment ewangelicznej perykopy penitent już kiedyś usłyszał, słyszy go i teraz w akcji liturgicznej sprawowanego sakramentu pojednania i może usłyszeć go w czasie niedzielnej eucharystii, bądź odkryje go na nowo w osobistej lekturze Biblii. Gdy spowiedź połączona jest ze mszą św. w kaplicy szpitalnej bądź na oddziale warto wcześniej przemedytować liturgię słowa i z jej bogactwa zaczerpnąć myśli do pasterskiego dialogu w czasie sprawowania sakramentu pokuty i pojednania ${ }^{17}$.

W końcu istotne znaczenie w kontekście refleksji nad językiem ma również zachowanie milczenia w rożnych momentach sprawowania tego sakramentu. Wielu pacjentów potrzebuje o wiele dłuższej chwili skupienia po wstępnej wspólnej modlitwie zakończonej słowami: „Niech Pan będzie w twoim sercu i na twoich wargach, abyś skruszony (skruszona) w duchu wyznał (wyznała) swoje grzechy". Momenty wzruszenia

16 Por. J. Lin, D.J. Kavanagh, E.A. Holmes, C. Macleod, M. Di Simplicio, Mental imagery in psychiatry: Conceptual and clinical implications, „CNS Spectrums” 24 (2019) nr 1, s. 114-126.

17 Por. K. Bardski, Chrześcijańska lektura Starego Testamentu w kluczu symboliki literackiej, „Rocznik Teologiczny” 57 (2015) nr 4, s. 447-457. J. Piper, Reading The Bible supernaturally, Wheaton 2017, s. 367. 
związane z wyznaniem grzechów bądź opisem życiowej sytuacji pacjenta należy uszanować milczeniem i chwilą ciszy, ze swej strony wypełniając ją cichą modlitwą ${ }^{18}$.

\section{Wskazania dla spowiadających osoby z zaburzeniem psychicznym}

Każda spowiedź powinna być osobistym i indywidualnym doświadczeniem dla penitenta, gdyż jest ona łaską od Boga ofiarowaną człowiekowi w konkretnej sytuacji życiowej. Zasady ogólne dotyczące tego sakramentu mocno podkreślają, że jest to przestrzeń działania miłosierdzia i właśnie ten aspekt należy przy spowiedzi mocno zaakcentować19. By spowiedź osób z zaburzeniem psychicznym była przez nie dobrze przeżyta, należy zwrócić szczególną uwagę na powyższy postulat oraz postarać się o dodatkowe okoliczności, dostosowane do ich sytuacji. Propozycje zasad, które należy wziąć pod uwagę w tym przypadku, zostaną zaprezentowane na podstawie pięciu konstytutywnych warunków dobrej spowiedzi, które pozostają podstawowym kryterium przeżywania tego sakramentu w formacji korzystającej z niego osób ${ }^{20}$.

Otoczenie osoby dotkniętej zaburzeniem psychicznym mocno wpływa na jej samopoczucie i możliwość współpracy, dlatego należy zadbać o warunki wstępne, w których ma być sprawowany sakrament pokuty i pojednania. Priorytetową wartością jest tutaj poczucie bezpieczeństwa i intymności. Szereg schorzeń psychicznych (szczególnie związanych z zespołami depresyjnymi i różnymi rodzajami schizofrenii) charakteryzuje się obecnością zaburzeń funkcji poznawczych. Również w procesie leczenia farmakologicznego silnymi lekami może mieć miejsce takie

18 M. Tatar, Milczenie w życiu duchowym człowieka w hałasie ponowoczesności, „Sympozjum” 36 (2019) nr 1, s. 61-81. W. Misztal, Cisza i milczenie: aktualność propozycji chrześcijańskiej, „Analecta Cracoviensia" 45 (2013), s. 185-203.

19 Por. Jan Paweł II, Reconcilatio et penitentia, dz. cyt., 5. Franicszek, Spowiedźnie jest sądem, ale doświadczeniem przebaczenia i miłosierdzia. Spotkanie z uczestnikami kursu dla spowiedników, 28.03.2014, „L'Osservatore Romano” 3-4 (2014), s. 38-39.

20 Por. J. Mizak, Formacyjny wymiar sakramentu pokuty, „Teologia i moralność” 10 (2011), S. $185-200$. 
zjawisko ${ }^{21}$. W tym kontekście dla właściwego przeżycia sakramentu pokuty i pojednania ważne jest zapewnienie dostatecznej słyszalności w połączeniu z poczuciem locum sacrum, gdzie ma on się odbywać. Spowiedź w miejscu konsekrowanym (kościół, kaplica szpitalna) będzie dawała poczucie świętości tego przeżycia i na ogół poprawia poziom identyfikacji religijnej. W zależności od stanu psychiki chorego, może to mieć istotny wpływ na świadomość, że aktualnie uczestniczy w liturgii, a nie w jednej spośród wielu czynności dnia codziennego ${ }^{22}$. Ze względu na wspomnianą już możliwość zaburzeń funkcji poznawczych (w tym słuchu) konfesjonał nie zawsze będzie odpowiednim miejscem dla takich osób, dlatego można wykorzystać pomieszczenia przy kościele/kaplicy szpitalnej, jeśli istnieje taka możliwość. W przypadku spowiedzi osób niehospitalizowanych z zaburzeniami psychicznymi należy ustalić z nimi, gdzie będzie najbardziej odpowiednie dla nich, ale też dla szafarza miejsce do przeżycia tego sakramentu. Niezbędna może okazać się wyraźna i głośniejsza komunikacja werbalna podczas tego sakramentu. Ustalając najbardziej odpowiednie warunki sprawowania sakramentu wobec pacjenta niehospitalizowanego (którego bliżej nie znamy) trzeba zwrócić uwagę na jego stan emocjonalny, w tym przede wszystkim na poziom lęku, stan pobudzenia, obecność objawów pozapiramidowych itd. Zawsze należy mieć na uwadze bezpieczeństwo własne i tym samym bezpieczeństwo naszego penitenta-pacjenta.

Doświadczenie pracy z pacjentami pokazuje, że część z nich przystępuje do sakramentu pokuty i pojednania w zaplanowany sposób, oczekując na przybycie kapłana lub samodzielnie umawiając się na spowiedź. Wielu przystępuje do sakramentu spontanicznie. Obydwie sytuacje maja wpływ na jakość rachunku sumienia, który może przybierać różne formy i skutkować skrajnym stanami poczucia winy: od bezgrzeszności po skrupulanckie wyrzuty sumienia. Podczas stałej pracy duszpasterskiej z konkretną osobą można wypracować schemat rachunku sumienia i pomóc go przeprowadzić. Pacjentom hospitalizowanym cennej pomocy

21 Por. S. Murawiec, Leki psychotropowe droga do zrozumienia połaczenia między umysłem a mózgiem, „Studia Philosophiae Christianae” 46 (2010) nr 2, s. 87-104.

22 Por. J. Klimek, Duszpasterstwo..., dz. cyt., s. 313. 
w tym zakresie mogą udzielić zespoły wsparcia duszpasterskiego złożone ze świeckich asystentów pastoralnych, mające $\mathrm{z}$ nimi stały kontakt. Dzięki permanentnej współpracy z pacjentami zespoły te przygotowują do korzystania z sakramentów i kierują do kapelana, co często jest kontynuacją wsparcia otrzymanego podczas rozmowy duszpasterskiej ${ }^{23}$. Dla osób z zaburzeniami o charakterze lękowym i nerwicowym, postrzegającym Boga jako oceniającego i wymagającego sędziego, taki rachunek powinien być prosty, opierający się na jasnych normach (np. dekalog lub siedem grzechów głównych), i zwięzły. Z jednej strony zbytnie rozbudowanie go może spowodować narastanie wyrzutów sumienia, które należy oddzielać od treści psychotycznych powstających w umyśle chorych. Z drugiej zaś strony można spotkać się z obojętnością na zło u chorych, którzy mają zaburzenia pamięci lub są po prostu niewłaściwie uformowani duchowo. Niektóre zaburzenia psychiczne mają swoje źródło w patologiach przeżywanych w okresie dzieciństwa i dojrzewania, a takie doświadczenia środowiska sprzyjają oddaleniu od Boga ${ }^{24}$. Dobrze przeprowadzony rachunek sumienia uwzględnia nie tylko grzechy, ale również postęp, rozwój moralny i doświadczone lub okazane w życiu dobro. Wówczas staje się okazją do spojrzenia na własne życie w praw$\mathrm{dzie}^{25}$. Ma to szczególne znaczenie dla chorych dotkniętych depresją i innymi schorzeniami charakteryzującymi się obniżeniem nastroju i niską samooceną, gdyż stanowi przeciwwagę dla ich destrukcyjnego obrazu własnej egzystencji ${ }^{26}$. Chodzi tu o zjawisko nazywane self-stigma (autostygmatyzacja) bądź „efektem przewidywanego odrzucenia”. Sakrament pokuty winien przyczyniać się do pomniejszania deficytów

${ }^{23}$ Por. J. Berlińska, J. Klimek, Poradnia pastoralna przy Rektoracie pw. Matki Bożej Częstochowskiej na terenie Szpitala Specjalistycznego im. dr. Józefa Babińskiego w Krakowie. Projekt, w: Odnaleźć wykluczonych, red. J. Dziedzic, J. Klimek, Kraków 2014, s. 191-211.

24 Por. A. Grzywa, Kultura a zaburzenia psychiczne, „Psychiatria” 14 (2017) nr 3, s. 129-134.

25 Por. W. Kawecki, Spowiedź a kształtowanie sumienia, „Homo Dei” 71 (2001) nr 1, s. 36-46.

${ }_{26}$ Por. D. Lizak, J. Drąg, A. Goździalska, R. Satora, J. Jaśkiewicz, Depresja jako przykład destrukcyjnego wpływu obniżonego nastroju na sferę bio-psycho-społeczna człowieka, w: Działania opiekuńcze w profilaktyce i terapii, red. A. Goździalska, J. Jaśkiewicz, G. Dębska, Kraków 2014, s. 19-26. 
penitenta-pacjenta i powiększania jego zasobów ${ }^{27}$. Należy też wspomnieć o zjawisku „zblednięcia emocji” oraz o nieadekwatnych zachowaniach emocjonalnych wśród osób leczonych psychicznie. Spowodowane są one bądź objawami wytwórczymi w procesie psychotycznym bądź działaniem neuroleptyków.

Kolejnym etapem jest wzbudzenie szczerego żalu za grzechy. W przypadku osób z zaburzeniem psychicznym może to być problematyczny moment, gdyż ogromny wpływ na zdolność wzbudzenia w sobie żalu ma świadomość popełnionych czynów. Ogólne obniżenie świadomości może spowodować konieczność dodatkowego wyjaśnienia osobom z poważnym zaburzeniem rozróżnienia tego, jakie postawy są dobre, a jakie złe. Należy tutaj przyjąć właściwą perspektywę oceny czynów moralnych, adekwatną do stanu psychiki spowiadającego się. W skrajnych przypadkach może się okazać, że chory jest zdolny jedynie do rozróżnienia ogólnego dobra lub zła w kontekście najbardziej podstawowych wartości takich, jak np. praktykowanie modlitwy, sposób wypowiedzi do innych osób w najbliższym otoczeniu, troska o własne życie, posłuszeństwo wobec wskazań zespołu medycznego. Odstawianie wskazanych przez lekarza środków farmakologicznych, które w przypadku innych schorzeń może mieć mniejszą winę moralną, w wypadku osób z zaburzeniem psychicznym jest bardzo poważnym wykroczeniem znacząco obniżającym lub uniemożliwiającym prowadzenie terapii, a często zagrażającym zdrowiu i życiu pacjenta ${ }^{28}$.

Koncepcja zła powinna być maksymalnie prosta i uwzględniać powszechne powołanie do świadczenia dobra wobec innych oraz to, że zaniedbania w tej sferze również wymagają żalu. Dotyczy to szczególnie osób, które nie widzą niczego niewłaściwego w popełnionych czynach i ciężko jest wzbudzić w nich za nie skruchę ${ }^{29}$. Podczas udzielania sakramentu pokuty i pojednania należy zwrócić również uwagę na możliwość niedyspozycji chorego do otrzymania rozgrzeszenia. Najczęściej

27 Por. J. Angst, V. Ajdacic-Gross, W. Rössler, Klasyfikacja zaburzeń nastroju, „Psychiatria Polska" 49 (2015) nr 4, s. 663-671.

28 Por. I. Krupka-Matuszczyk, M. Matuszczyk, Psychiatria. Podręcznik dla studentów pielegniarstwa, Katowice 2007, s. 61-62.

${ }_{29}$ Por. J. Łukomski, Dlaczego zło?, „Kieleckie Studia Teologiczne” 1 (2010) nr 2, s. 201-210. 
wynika to z trwania w nieregularnym związku, który powoduje stałą okazję do grzechu. Zaburzenie psychiczne nie powinno być żadną ulgą dla tych, którzy mogą rozeznać, że ich sytuacja życiowa jest obarczona stałą okazją do grzechu ciężkiego. Również pacjenci hospitalizowani, którzy przebywają dłuższy czas na leczeniu, a stale są w takiej sytuacji, mogą mieć przeszkodę do otrzymania rozgrzeszenia, jeśli nie wykazują należytej skruchy i nie widzą możliwości trwałej zmiany swojego życia. Trzeba wówczas spokojnie i jasno wytłumaczyć przyczyny braku dyspozycji do rozgrzeszenia ${ }^{30}$. Należy też wspomnieć o zjawisku „zblednięcia emocji" oraz o nieadekwatnych zachowaniach emocjonalnych wśród osób leczonych psychicznie. Spowodowane są one bądź objawami wytwórczymi w procesie psychotycznym, bądź działaniem neuroleptyków.

Postanowienie poprawy wymaga od penitenta wiary w to, że jego życie może ulec zmianie na lepsze. Osoby z zaburzeniami psychicznymi często są pozbawione jakiejkolwiek nadziei na jakościową zmianę egzystencji. Ich sytuacja rodzinna i osobista często staje się dodatkowym bodźcem uniemożliwiającym osiągnięcie tej cnoty. Podczas stałej pracy z takim człowiekiem należy ukierunkowywać go na małe krótkoterminowe cele, które będą mogły być realizowane także przy okazji zadanej pokuty. W tym miejscu duszpasterz ma szczególne zadanie do spełnienia, gdyż pobudzając osobę chorą do wiary w możliwość poprawy jej stanu duchowego, jednocześnie motywuje ją do całościowej pracy nad sobą. W ten sposób może stać się ważnym ogniwem podczas terapii i nawiązać efektywną współpracę z zespołem terapeutycznym. Wiele badań wskazuje na potrzebę motywacji i jej wysoki wpływ na jakość terapii osób dotkniętych zaburzeniem psychicznym na początku podejmowanego leczenia ${ }^{31}$.

Podczas wyznania grzechów nie można zapomnieć, że w centrum sakramentu pokuty i pojednania jest przede wszystkim miłosierdzie Boga, który z czułością szuka i przyjmuje każdego grzesznika ${ }^{32}$. Dotych-

30 Por. K. Paluch, Obowiazki i zadania spowiednika, „Sympozjum” 30 (2016) nr 1, s. 9-26.

31 Por. M. Libman-Sokołowska, T. Nasierowski, Rola nadziei w zmaganiach ze schizofrenia, „Psychiatria Polska” 47 (2013) nr 5, s. 933-946.

32 Por. Franciszek, Bóg kocha z czułością nawet największych grzeszników, https://www.vaticannews.va/pl/papiez-franciszek/msza-w-domu-sw-marty/2019-10/papiez-bog-kocha-z-czuloscia-nawet-najwiekszych-grzesznikow.html (6.05.2020). 
czasowe wnioski sugerują, że dla osób z zachwianym stanem psychiki może się okazać konieczna pomoc przy wyznaniu grzechów i określeniu ich treści, co dotyczy szczególnie osób zobojętniałych, podchodzących do spowiedzi zbyt powierzchownie. Jednocześnie u osób z zaburzeniami świadomości, często obserwuje się stratyfikacje treści przechowywanych w pamięci skutkujące sprawnym wyodrębnieniem grzechów i przytomną oceną moralną swoich czynów, pomimo pomijania innych istotnych faktów z ich życia ${ }^{33}$. Drugą skrajnością jest przeciągające się, skrupulanckie wyznawanie swoich grzechów. W tym przypadku można delikatnie podkreślić, że dany problem powtarza się i zachęcić do bardziej ogólnego wypowiedzenia grzechów. Należy też zwrócić szczególną uwagę na wypowiadaną formułę i podkreślić konieczność wyrażenia swojego żalu oraz chęci poprawy. Pouczenie powinno dotyczyć bezpośrednio problemów poruszonych przy wyznaniu grzechów i skupić się na kwestiach najbardziej koniecznych do zmiany. Jednym z najpoważniejszych błędów, jakie można popełnić na tym etapie sakramentu pokuty i pojednania to aplikacja wskazań i teorii sprzecznych z prowadzoną wobec chorego terapią ${ }^{34}$.

Ostatnim etapem sakramentu pokuty i pojednania jest zadośćuczynienie Bogu i bliźniemu, które powinno być dostoswane do indywidualnych możliwości penitenta. Dla spowiadającego się z objawami depresji i obniżonego nastroju budujące będzie zadanie pokuty, w której będzie musiał skupić się na pozytywnych wartościach swojego życia lub analizie tekstu dającego nadzieję. Osoby z objawami nerwicowymi powinny otrzymać pokutę krótką i jednoznaczną, która będzie mogła być odmówiona w łatwy sposób, niejako „mechanicznie”, co pozwoli im mieć pewność dopełnienia tego warunku spowiedzi ${ }^{35}$. Ja w swojej praktyce sprawowania tego sakramentu staram się pokutę odmówić wraz z penitentem-pacjentem zaraz po słowach rozgrzeszenia. Warto wyraźnie dać to do zrozumienia penitentowi, zachęcając na przykład: „A teraz razem

\footnotetext{
R. Mazur, M. Klimarczyk, M. Trzcińska, W. Rajczyk, Zaburzenia..., dz. cyt., s. 51-58.

34 Por. J. Prusak, Psychiatria i religia - partnerzy czy rywale, w: Między konfesjonałem a kozetka, red. K. Jabłońska, C. Gawryś, Warszawa 2010, s. 220-236.

35 Por. J. Hershfield, Zaburzenia obsesyjno-kompulsywne. Poradnik oparty na uważności i terapii poznawczo-behawioralnej, tłum. M. Kacprzak, Kraków 2016, s. 90.
} 
(wspólnie) odmówmy pokutę". Dla szafarza jest to również ważna okazja do modlitwy za chorego. Pacjenci hospitalizowani mogą mieć trudności z zadośćuczynieniem bliźniemu, szczególnie osobom pozostającym poza miejscem leczenia. Stan psychiki może znacznie ograniczać możliwość jakiejkolwiek formy zadośćuczynienia, przeprowadzonego samodzielnie. Po rozeznaniu takiej sytuacji, należy znów sprowadzić go do modlitwy wypowiadanej razem, odmówić pokutę wraz ze spowiadającym się tuż po udzieleniu rozgrzeszenia. Stworzy to pewność wypełnienia istotnego warunku spowiedzi oraz pozwoli na zbudowanie wspólnoty modlitwy, co jeszcze bardziej zacieśni relacje między duszpasterzem a takim penitentem ${ }^{36}$.

\section{Zakończenie}

Spowiedź osób z zaburzeniami psychicznymi jest posługą świadczoną w ramach duszpasterstwa specjalistycznego. By mogła być owocna i odnosić trwałe skutki duchowe, jej szafarze powinni być przygotowani na specyficzne warunki pracy z takimi penitentami. Podstawy samego sakramentu są niezmienne, jednak sytuacje towarzyszące i odmienne postrzeganie świata przez dotkniętych dysfunkcjami psychicznymi wymagają dodatkowego wysiłku i empatii ze strony kapłana. Innym utrudnieniem jest duże zróżnicowanie zaburzeń i możliwości osób dotkniętych nimi, dlatego jakość tego sakramentu zależy od umiejętności indywidualnego podejścia przez spowiednika. Nie wolno przy tym zapomnieć, że przeżywający zaburzenie psychiczne są częścią Kościoła, którego podstawowym zadaniem jest umożliwienie im zbawienia, także poprzez żal za popełnione grzechy i próbę rehabilitacji.

36 Por. S. Mieszczak, Liturgia jako miejsce budowania wspólnoty, „Sympozjum” 29 (2015) nr 2, s. 51-64. 


\section{Bibliografia}

Andersch A., Symbolic Form and Mental Illness: Ernst Cassirer's Contribution to a New Concept of Psychopathology, w: The Philosophy of Ernst Cassirer: A Novel Assessment, ed. S. Luft, J.T. Friedman, Berlin 2015.

Angst J., Ajdacic-Gross V., Rössler W., Klasyfikacja zaburzeń nastroju, „Psychiatria Polska" 49 (2015) nr 4, s. 663-671.

Bardski K., Chrześcijańska lektura Starego Testamentu w kluczu symboliki literackiej, „Rocznik Teologiczny” 57 (2015) nr 4, s. 447-457.

Benedykt XVI, Otaczajmy troską i mitościa umysłowo chorych. Orędzie Ojca Świętego na XIV Światowy Dzień Chorego 2006, https://opoka.org.pl/biblioteka/W/WP/benedykt_xvi/przemowienia/chory2006-or_08122005.html (22.05.2020).

Berlińska J., Klimek J., Poradnia pastoralna przy Rektoracie pw. Matki Bożej Częstochowskiej na terenie Szpitala Specjalistycznego im. dr. Józefa Babińskiego w Krakowie. Projekt, w: Odnaleźć wykluczonych, red. J. Dziedzic, J. Klimek, Kraków 2014.

Czernikiewicz A., Jak żyć ze schizofrenia - poradnik dla pacjentów i ich rodzin, Lublin 2009.

De Barbaro B., Najlepiej pomoc równoległa, „Więź” 2 (2004) nr 544, s. 21-22.

Dołęga J.M., Analiza pojęcia symbolu, „Studia Philosophiae Christianae” 39 (2003) nr 2, s. 77-95.

Draguła A., Papieża Franciszka metafory Kościoła, „Colloquia Theologica Ottoniana” 2018 nr 1, s. 159-177.

Franciszek, Bóg kocha z czułościa nawet największych grzeszników, https://www.vaticannews.va/pl/papiez-franciszek/msza-w-domu-sw-marty/2019-10/papiez-bog-kocha-z-czuloscia-nawet-najwiekszych-grzesznikow.html (6.05.2020).

Franciszek, Kościół ma być znakiem miłosierdzia Pana. Przemówienie do uczestników międzynarodowego spotkania nt. Evangelii gaudium, 19.09.2014, „'O'Osservatore Romano" 10 (2014), s. 32-33.

Franciszek, Spowiedź nie jest sąem, ale doświadczeniem przebaczenia i miłosierdzia. Spotkanie z uczestnikami kursu dla spowiedników, 28.03.2014, „L'Osservatore Romano" 3-4 (2014), s. 38-39.

Grzywa A., Kultura a zaburzenia psychiczne, „Psychiatria” 14 (2017) nr 3, s. 129-134.

Hershfield J., Zaburzenia obsesyjno-kompulsywne. Poradnik oparty na uważności i terapii poznawczo-behawioralnej, tłum. M. Kacprzak, Kraków 2016.

Jacko J.F., Struktura symboli wertykalnych a ich rola $w$ komunikacji międzykulturowej i w zarzadzaniu, „Space-Society-Economy” 7 ( 2005) nr 7, s. 176-183.

Jan Paweł II, Mężczyzna i niewiasta stworzył ich. Chrystus odwołuje się do zmartwychwstania, Lublin 2006.

Jan Paweł II, Reconcilatio et penitentia, Wrocław 1997.

Katechizm Kościoła katolickiego, Poznań 1994.

Kawecki W., Spowiedź a kształtowanie sumienia, „Homo Dei” 71 (2001) nr 1, s. 36-46.

Klimek J., Duszpasterstwo w kobierzyńskiej kapelanii na przestrzeni wieku, Kraków 2019.

Kłoczowski A., Sumienie a superego, czyli paradoksalna bliskość Tomasza z Akwinu i Freuda, w: Między konfesjonałem a kozetka, red. K. Jabłońska, C. Gawryś, Warszawa 2010. 
Kodeks Prawa kanonicznego, Poznań 1984.

Jan Paweł II, Reconcilatio et penitenitia, http://www.vatican.va/content/john-paul-ii/pl/apost_exhortations/documents/hf_jp-ii_exh_02121984_reconciliatio-et-paenitentia.html (20.12.2020).

Kotowa K., Punkty styczne, „Więź” 2 (2004) nr 544, s. 26.

Krąpiec M., Człowiek i prawo naturalne, Lublin 1993.

Krupka-Matuszczyk I., Matuszczyk M., Psychiatria. Podręcznik dla studentów pielęgniarstwa, Katowice 2007.

Kurpas D., Miturska H., Podstawy psychopatologii i syndromologii ogólnej, w: Podstawy psychiatrii dla studentów pielegniarstwa, red. D. Kupis, H. Miturska, M. Kaczmarek, Wrocław 2009.

Libman-Sokołowska M., Nasierowski T., Rola nadziei w zmaganiach ze schizofrenia, „Psychiatria Polska” 47 (2013) nr 5, s. 933-946.

Lin J., Kavanagh D.J., Holmes E.A., Macleod C., Di Simplicio M., Mental imagery in psychiatry: Conceptual and clinical implications, „CNS Spectrums” 24 (2019) no. 1, s. 114-126.

Lizak D., Drąg J., Goździalska A., Satora R., Jaśkiewicz J., Depresja jako przykład destrukcyjnego wpływu obniżonego nastroju na sferę bio-psycho-społeczna człowieka, w: Działania opiekuńcze w profilaktyce i terapii, red. A. Goździalska, J. Jaśkiewicz, G. Dębska, s. 19-26.

Łukomski J., Dlaczego zło?, „Kieleckie Studia Teologiczne” 1 (2010) nr 2, s. 201-210.

Mazur R., Klimarczyk M., Trzcińska M., Rajczyk W., Zaburzenia świadomości - spojrzenie interdyscyplinarne, „Polski Przegląd Neurologiczny” 10 (2014) nr 2, s. 51-58.

Mieszczak S., Liturgia jako miejsce budowania wspólnoty, „Sympozjum” 29 (2015) nr 2, s. 51-64.

Misztal W., Cisza i milczenie: aktualność propozycji chrześcijańskiej, „Analecta Cracoviensia" 45 (2013), s. 185-203.

Mizak J., Formacyjny wymiar sakramentu pokuty, „Teologia i moralność” 10 (2011), s. 185-200.

Molenda A., Wybrane aspekty nerwicy eklezjogennej. Perspektywa psychoterapeuty, w: Religia, religijność, duchowość: w poszukiwaniu nowych perspektyw: księga jubileuszowa dla Pawła M. Sochy od przyjaciół i uczniów, red. H. Grzymała-Moszczyńska, D. Motak, Kraków 2015, s. 189-199.

Murawiec S., Leki psychotropowe droga do zrozumienia połaczenia między umysłem a mózgiem, „Studia Philosophiae Christianae” 46 (2010) nr 2, s. 87-104.

Niewiadomski L., Integralnie, „Więź” 2 (2004) nr 544, s. 30.

Paluch K., Obowiązki i zadania spowiednika, „Sympozjum” 30 (2016) nr 1, s. 9-26.

Piper J., Reading The Bible supernaturally, wheaton 2017.

PrusakJ., Psychiatria i religia - partnerzy czy rywale, w: Między konfesjonałem a kozetka, red. K. Jabłońska, C. Gawryś, Warszawa 2010, s. 220-236.

Prusak J., Rozróżnianie sumienia od superego u osób religijnych w kontekście pracy z nerwica eklezjogenna, „Psychoterapia” 4 (2016) nr 179, s. 33-44. 
Tatar M., Milczenie w życiu duchowym człowieka w hałasie ponowoczesności, „Sympozjum" 36 (2019) nr 1, s. 61-81.

Walczak M., Problem tak zwanego obrazu Boga w świetle tezy Paula Tillicha o objawieniu finalnym, „Teologia w Polsce” 10 (2016) nr 2, s. 197-207. 